\title{
CORRESPONDENCE
}

\section{Scientists who act}

SIR - Sir Peter Medawar's review of Martin Gardner's book "Science: Good, Bad and Bogus' (Nature 28 January, p.351), criticizes people working in fringe science, scientists who step aside from their specialisms to apply their experience in other areas and the inexperienced whose opinions force them into a corner where they grimly hold on to their untenable theories. He paints a broad canvas of condemnation and thereby implies that most speculation is put forward by rogues motivated by profit or starved of recognition and that we on the receiving end are unable to distinguish between the possible, probable and downright foolish.

Sir Peter's attack questions the integrity of scientists whose imaginative speculations, right or wrong, stimulate action that eventually leads to the truth. He makes use of the reference to unnamed people - the astronomer, microbiologists - without stating his objections. Above all, Sir Peter forgets that absence of proof is not proof of absence. Truth prevails eventually and the speculations and experiments that lead to it are winnowed by time.

Sir Peter's preoccupation with the intellectual underworld does disservice to those who think as well as labour in their laboratories. Also to those who in these difficult times are without laboratories and who have only their thoughts to offer to the service of human understanding.

Leystonstone,

D.G. Applin

London, UK

\section{Doves in false garb}

SIR - The leading article "Doves in false garb" (Nature 18 February, p.542) asks "What other justification is there for the Medical Campaign against Nuclear War except that physicians prefer hobnobbing with other physicians than with the hoi polloi?'” This is a cheap shot unworthy of Nature. Let us hear some specific criticism of the physicians' proposals, let us hear some refutation of the plentiful justifications offered for the campaign by the physicians, but let us not hear "Nyah, nyah, nyah."

As the present American government considers a nuclear war ever more wageable and winnable, physicians must also begin ever more often to picture themselves crawling about on radioactive heaps attempting to dispense medicine in the aftermath of victory. The hope for curing anybody is less than small. Physicians claim that a nuclear war is a terminal disease for entire nations. When a doctor helps us to not catch a disease this is called preventative medicine. Such help is not only legitimate for a doctor to offer but may be felt required by the Hippocratic oath. Physicians involved in the aforementioned campaign are doing what they perceive is their duty to keep their patients alive. Does Nature doubt this prognosis? Do you share the opinion of the Federal Emergency Management Agency to the effect that society (at least that of the United States) will totally recover from a full-scale nuclear war within two to four years?

Nature concludes this commentary with the suggestion that if physicians, or any other professional group's members, seek to influence policy they should become members of parliament. This suggestion is nonsense. It is precisely because physicians are not politicians that they may help bring significant arms control into being. In past comment (Nature 294, 197; 295, 270) Nature has both stated the evident desirability of serious arms control negotiations and depicted the bumbling attempts of (US) politicians to initiate them. Atomic and hydrogen bombs now proliferate faster than ever before and members of parliament $e t$ al. have been as yet unable to inhibit this malignant growth. To stop and reverse the arms race will require the efforts of people in all walks of life acting in ways often without precedent, of ten compelled by personal, moral feeling.

Nature owes the living minds of its readers mature and honest evaluations of proposals from any campaign against nuclear war.

TOBIAS ISAAC BASKIN

Stanford Mid-Peninsula Chapter,

Physicians for Social Responsibility,

Stanford, California, USA

\section{Mutualistic lives}

SIR - In his News and Views article, "Mutualism: New Ecological Theories", May' asserts that ". . . conspicuous mutualistic associations tend to be tropical ones". May I suggest that conspicuousness is in the eye of the beholder? All the examples he cites involve animals. From ericaceous heaths of arctic-alpine regions, through vast acreages of boreal forest and temperate grasslands to tropical rain forests, the structure of the plant communities is governed, to those with the eye for them, by the conspicuous associations between plants and their mutualistic mycorrhizal fungi (see, for example, refs 2-6).

Mutualistic associations between plants and nitrogen-fixing prokaryotes and lichens are also important in tropical and non-tropical, especially sub-arctic, zones 7,8 . Harley 9,10 , myself ${ }^{11}$ and others have bemoaned the slow recognition by taxonomists and ecologists of the importance of mutualistic fungi and bacteria to plants in all terrestrial ecosystems. Let us hope that another of May's assertions ${ }^{1}$ - that empirical and theoretical studies of mutualistic associations are likely to be one of the growth industries of the $1980 \mathrm{~s}$ - will be world-wide and encompass interactions between all five kingdoms of organisms ${ }^{12}$.

\section{D.H. LEWIS}

The University,

Sheffic!d, UK

1. May, R.M. Nature 296, 803 (1982)

2. Harley, J.L. The Biology of Mycorrhiza, 2nd edn (Hill, London, 1969).

. Janos, D.P. Biotropica 12, 56 (1980)

4. Malloch, D.W., Pirozynski, K.A.\& Raven, P.H. Proc. natn. Acad. Sci. U.S.A. 77, 2113 (1980)

5. Malajczuk, N. \& Lamont, B.B. in Ecosystems of the World, Vol.9B Heathlands and Related Shrublands: Analytical Studies (ed. Specht, R.L.) 165 (Amsterdam, Elsevier, 1981).

6. Read, D.J. Can. J. Bot. (in the press).
7. Sprent, J.1. The Biology of Nitrogen-fixing Organisms (McGraw-Hill, London, 1979).

8. Hale, M.E. The Biology of Lichens, 2nd edn (Arnold, London, 1974).

9. Harley, J.L. New Phytol. 67, 979 (1968).

10. Harley, J.L. in Ecological A spects of the Mineral Nutrition of Plants (ed. Rorison, I.H.) 437 (Blackweli, Oxford, 1969).

11. Lewis, D.H. in Taxonomy and Ecology (ed. Heywood, V.H.) 151 (Academic, London, 1973)

12. Margulis, L. \& Schwartz, K.V. Five Kingdoms. An Illustrated Guide to the Phyla of Life on Earth (Freeman, San Francisco, 1982).

\section{Kin to whom?}

SIR - Kin selection is not normally used by students of mammalian social evolution to explain the sociobiology of a particular class 1,2 . Contrary to the assertions by Packer and Pusey (Nature 22 April, p.740), Boorman and Levitt ${ }^{3}$ (p.250) derived the conclusion that "attempts to apply $k>(1 / r)$ directly to the analysis of primate, carnivore or other mammalian societies should be evaluated very cautiously" from their thorough review of the literature on mammals.

Students of vertebrate social systems have recognized the importance of the "multimale" group, selection for outbreeding, and reciprocal associations between unrelated males for social evolution in the mammals, and the implications of these classical features for the genetic and phenotypic structures of mammalian, including human, populations have been discussed ${ }^{1,4-9}$. It is the persistence of these features that leads some primatologists to conclude that macaques and baboons, rather than gorillas or chimpanzees, are the richest models extant of hominid evolution 10,11. Further, numerous "theoretical analyses" have pointed out that "inclusivefitness maximizing"' and kin selection are not equivalent and that under certain competitive regimes, kin may be "ego's" worst enemies ${ }^{12-14}$. Packer and Pusey's appreciation that individual reproductive "games" may not often be explained by kin selection for the mammals follows from the literature on behaviour and social evolution in that class.

Museum of Comparative Zoology, Clara B. Jones

Harvard University, Cambridge,

Massachusetts, USA

1. McCracken, G. \& Bradbury, J, Science 198, 303-306 (1977)

2. Schwartz, O.A. \& Armitage, K.B. Science 207, 665-667 (1980).

3. Boorman, S.A. \& Levitt, P.R. The Genetics of Altruism Academic, New York, 1980).

4. Trivers, R.L. Q. Rev. Biol. 46, 35-57 (1971).

5. Eisenberg, J.F. Handb. Zool, 10, 1-97 (1966).

6. Eisenberg, J.F., Muckenhirn, N.A. \& Rudran, R. Science $176,863-874$ (1972)

7. Alexander, R.D. et al. in Evolutionary Biology and Human Social Behavior: An Anthropological Perspective (eds Chagnon, N.A. \& Irons, W.) 402-435 (Duxbury, North Scituate, Massachusetts, 1979).

8. Brown, J.L. The Evolution of Behavior (Norton, New York, 1975).

9. West-Eberhard, M. J. Proc, Am. Phil. Soc. 123, 222-234 (1979).

10. Washburn, S.L.\& DeVore, 1. Scient. Am. 614, 2-11 (1961).

11. Tiger, L. Men in Groups (Random House, New York, 1969).

12. Alexander, R.D. A. Rev. Ecol. Syst. 5, 325-383 (1974).

13. Kurland, J A Ethol Sociobiol 1, 255-274 (1980)

14. Waded, M.J. \& Breden, F. Behav. Ecol. Sociobiol. 7. $167-172(1980)$ 